\title{
Program Mendengar Aktif untuk Ayah dengan Anak Usia 4 Hingga 6 Tahun
}

\author{
Oki Gunawan1, \\ Puji Lestari Suharso, \\ Dini Pepen Daengsari \\ Program Magister Psikologi Terapan Anak Usia Dini \\ Fakultas Psikologi Universitas Indonesia
}

\begin{abstract}
Today, fathers are more involved in children's caretaking. This role has shifted the views about family. Fathers who had the function as breadwinners are now also taking the role as caregivers. Unfortunately there are still some inadequacy in caregiving by fathers, especially in communicating with children. This issue needs to be handled because father's competence in caregiving affects the development of the children to produce positive behavior. Fathers need an intervention to increase their knowledge and skills to communicates with children. One intervention that gives maximum effect is by trained fathers to increase knowledge and skills on active listening. This research is a one group pretest and posttest design type which involved 5 young adult fathers with children aged 4-6 years old and was performed in Depok, West Java. The final result shows a significant differences in fathers' active listening knowledge and skills before and after receiving the father active listening program.
\end{abstract}

Keywords: training; active listening; father; early age children; caregiving; fathering

\begin{abstract}
ABSTRAK: Fenomena meningkatnya peran dan keterlibatan ayah dalam pengasuhan anak, membuat ayah yang dulu dianggap hanya berperan sebagai pencari nafkah (breadwinner) kini juga ikut berperan sebagai pengasuh (caregiver). Akan tetapi masih terdapat kekurangan dalam proses pengasuhan yang dilakukan oleh ayah, khususnya dalam hal berkomunikasi dengan anak. Hal ini perlu diatasi karena peran ayah dalam pengasuhan turut mempengaruhi perkembangan anak, khususnya menciptakan tingkah laku yang positif. Ayah membutuhkan sebuah intervensi untuk dapat meningkatkan kualitas komunikasi dengan anak. Intervensi yang diberikan bertujuan untuk meningkatkan pengetahuan dan keterampilan ayah dalam mendengar aktif. Penelitian ini merupakan penelitian dengan one group pretest posttest design. Penelitian dilakukan di Depok, Jawa Barat dengan melibatkan partisipan 5 orang ayah yang memiliki anak berusia 4-6 tahun. Dari hasil penelitian diketahui bahwa pelatihan mendengar aktif untuk ayah mampu meningkatkan pengetahuan dan keterampilan mendengar aktif ayah dalam pengasuhan anak berusia 4-6 tahun. Dari hasil data analisis statistik juga ditemukan peningkatan yang signifikan pada pengetahuan dan keterampilan ayah setelah mendapatkan intervensi pelatihan.
\end{abstract}

Kata kunci: pelatihan: mendengar aktif; ayah; anak usia dini; pengasuhan; fathering

${ }^{1}$ Korespondensi mengenai isi artikel ini dapat dilakukan melalui: okigunawan1983@gmail.com. 
Ayah adalah salah satu figur paling penting dalam kehidupan seorang anak. Bersama dengan ibu, ayah berperan sebagai orangtua yang memiliki peran memberikan pengasuhan dan memenuhi kebutuhan hidup anak (Brooks, 2001). Dalam pandangan tradisional yang dianut masyarakat, ayah diidentifikasikan sebagai sosok yang bertugas untuk mencari nafkah (breadwinner) sementara ibu bertugas utama mengasuh anak. (Mc.Bride, 2005). Dalam kurun waktu beberapa dekade terakhir muncul perubahan dalam pandangan mengenai peran ayah yang terjadi di beberapa negara maju. Para ayah mulai menambah jumlah waktu yang mereka habiskan untuk mengasuh anakanak mereka dan saat ini sudah lebih banyak para ayah yang ikut mengasuh anak dibandingkan dengan para ayah pada generasi sebelumnya (Pleck \& Masciadrelli, 2004). Fenomena yang sama juga terjadi di Indonesia yang ditandai dengan menjamurnya studi dan seminar parenting yang membahas mengenai peran ayah, berkembangnya komunitas pengasuhan yang dimotori oleh para ayah serta maraknya karya sastra dan film yang mengambil tema mengenai peran ayah dalam pengasuhan anak.

Menurut Pleck (2010), peran ayah dalam pengasuhan turut mempengaruhi perkembangan anak, khususnya membantu menciptakan tingkah laku positif. Jika hubungan yang terjadi positif, anak dapat mengembangkan kemampuan kognitif, memperoleh berbagai keterampilan (skill) yang dapat meningkatkan keterampilan sosial dan kematangan emosional. Jika hubungan yang terjadi negatif banyak masalah tingkah laku yang ditemukan tejadi pada anak saat beranjak remaja atau dewasa. Kurangnya keterlibatan ayah dalam pengasuhan dapat menjadi salah satu faktor penyebab masalah tingkah laku pada anak.
Dari penelitian Osborne dan McLanahan (2007), melalui Fragile Family Study yang mengambil sampel 2.111 keluarga, diketahui bahwa anak berusia 0-3 tahun memiliki tingkat agresivitas tinggi apabila dibesarkan tanpa mengikutsertakan keterlibatan ayah di dalamnya. Kurangnya keterlibatan ayah juga bisa berpengaruh terhadap perkembangan anak dalam tahap usia selanjutnya. Berdasarkan hasil penelitian ditemukan kecenderungan anak lebih rentan untuk terlibat tindak kriminal saat memasuki usia remaja jika kurang mendapat perhatian dari ayah mereka (Bronte-Tinkew, Moore, \& Carrano, 2006).

Sebaliknya, keterlibatan ayah yang tinggi dalam pengasuhan anak dapat berdampak positif bagi perkembangan anak. Bukti-bukti penelitian terbaru menunjukkan bahwa intensi keterlibatan ayah dalam pengasuhan yang tinggi memiliki keuntungan bagi perkembangan dan kesejahteraan anak (Lamb, 2010). Berdasarkan hasil penelitian Cooksey \& Fondell (1996) diketahui bahwa keterlibatan ayah pada kegiatan sehari-hari anak memiliki dampak positif terhadap prestasi akademis anak. Anak yang memiliki ayah yang aktif berinteraksi bersama dalam kegiatan mereka seperti makan bersama, menghabiskan waktu santai, terlibat dalam melakukan pekerjaan di rumah, membantu mereka dalam mengerjakan tugas sekolah, membaca buku bersama dan kegiatan sehari-hari lainnya menunjukkan kemampuan akademis yang lebih baik secara signifikan dibandingkan anak yang memiliki ayah yang kurang terlibat dalam kegiatan harian mereka. Berdasarkan hasil elisitasi peneliti pada kelompok ayah di Depok, diketahui bahwa ayah-ayah di daerah Depok telah memiliki kesadaran dan ikut terlibat dalam pengasuhan anak mereka. 
Dari banyak penelitian ditemukan juga ayah yang relatif sedikit waktunya dalam pengasuhan kepada anak. Penelitian Early Childhood Association (ECA) di India (DNA, 2012) diketahui bahwa ayah yang bekerja menghabiskan waktu hanya 8 menit untuk berbicara dengan anak. Dari penelitian yang sama didapatkan juga bahwa ayah sering kali tidak mengetahui apa yang sedang dialami anak termasuk soal pelajaran di sekolah. Ayah cenderung memberikan perintah kepada anak dan jarang berbicara kepada anak. Saat melakukan pembicaraan biasanya hanya berkisar tentang pelajaran di sekolah dan tidak kepada hal-hal yang lebih mendalam seperti perasaan anak. Sehingga dapat disimpulkan bahwa kesadaran ayah untuk ikut terlibat aktif dalam pengasuhan anak saja belum cukup untuk mengoptimalkan perkembangan anak. Ayah seharusnya memiliki pengetahuan dan keterampilan berkomunikasi yang baik untuk menunjang perkembangan anak mereka. Menurut McGraw (2004) dengan modal keterampilan komunikasi yang baik, ayah mampu membangun kebersamaan yang berkualitas saat bersama anak. Kualitas kebersamaan itu dapat terwujud bila ayah menjalin komunikasi dengan anak, mendengarkan kebutuhan anak dan memiliki rasa empati terhadap perasaan anak.

Berlandaskan fakta-fakta di atas, ayah harus memiliki pengetahuan dan keterampilan berkomunikasi yang penuh kasih sayang dengan anak agar dapat menjalankan tugas pengasuhan dengan baik, salah satu caranya adalah dengan mendengar aktif (active listening). Mendengar aktif merupakan salah satu cara yang efektif untuk membangun komunikasi dan interaksi dengan anak (Gordon, 2009). Mendengar secara aktif membutuhkan pemusatan perhatian yang menuntut keterlibatan hati, mata dan telinga serta menuntut kesabaran, kemampuan menyeleksi informasi sekaligus memahami dengan penuh toleransi (Rogers \& Farson, 1987). Dengan mendengar aktif komunikasi akan menjadi lebih berkualitas (Thomas, 2014). Saat orang tua mendengarkan anak mereka secara aktif, anak akan dapat berkembang menjadi pribadi yang terbuka dan interaksi antara orang tua dengan anak juga akan menjadi lebih hangat.

Olson dan Hergenhahn (2011) menyimpulkan pendapat Rogers yang mengatakan bahwa mendengar aktif merupakan suatu cara untuk mengenali dan memahami perasaan yang sesungguhnya dari lawan bicara. Mendengar merupakan komponen yang paling penting dalam sebuah proses komunikasi (Burley \& Allen, 1995). Dengan adanya kemampuan mendengar aktif maka kemampuan ayah untuk menempatkan diri pada situasi atau kondisi yang dihadapi anak pun akan meningkat dan akan lebih mudah memahami sudut pandang anak (Rogers \& Farson, 1987). Gordon (2009) menjelaskan bahwa mendengar aktif merupakan salah satu cara yang efektif untuk membangun komunikasi dan interaksi dengan anak. Dengan mendengar aktif komunikasi akan menjadi lebih berkualitas (Thomas, 2014). Anak hanya akan menjalin komunikasi dengan ayah jika ayah dapat mendengar secara aktif segala kebutuhan dan perasaan anak (McGraw, 2004). Motivasi anak untuk meraih keberhasilan juga akan berkembang apabila ayah berkomunikasi dengan anak dengan penuh kehangatan, selalu menyemangati, dan terbuka dalam diskusi dengan anak (Brooks, 2011).

Mengingat pentingnya pengetahuan mendengar aktif untuk menjalin hubungan yang baik antara ayah dan anak maka dirasa perlu untuk dilakukan intervensi kepada ayah. Salah satu bentuk intervensi yang bisa dilakukan kepada ayah dapat berbentuk pelatihan. Intervensi berupa pelatihan kepada ayah ditujukan untuk meningkatkan pengetahuan dan keterampilan komunikasi ayah kepada anak dengan menekankan 
pentingnya parafrase dan komunikasi yang bersifat empatik dengan anak sebagai dasar keterampilan mendengar aktif.

Mendengar aktif adalah bagian dari proses mendengar (listening). Listening (mendengar) adalah sebuah proses komunikasi yang terjadi saat penerima pesan menerima sinyal-sinyal komunikasi dari pengirim pesan. Listening melibatkan pengindentifikasian suara-suara, kemudian akan berproses menjadi kata-kata atau kalimat-kalimat (Tubbs, 2003). Robertson (2005) mendefinisikan mendengar aktif sebagai salah satu kemampuan dalam berkomunikasi yang melibatkan interaksi yang bersifat verbal maupun nonverbal dengan tujuan untuk memberikan atensi secara total dan tak terbagikan kepada lawan bicara serta mengindikasikan kepada lawan bicara bahwa pendengar tertarik dan peduli terhadap hal yang ia sampaikan. Mendengar aktif akan semakin efektif jika seseorang dapat mendengar dengan sensitif dan penuh perhatian (Rogers \& Farson, 2007). Mendengar aktif pertama kali dikemukakan Gordon (1994) untuk melatih orang tua agar mampu memahami anaknya secara menyeluruh. Dengan mendengar aktif, orang tua diharapkan dapat melakukan proses menyampaikan balik kepada anak pesan yang menurut orang tua dimaksud oleh anak, baik dari segi isi maupun perasaannya (Ramadhani, 2006). Mendengar aktif membutuhkan sikap empatik dari orang tua, sehingga bisa dengan secara tepat memberikan umpan balik kepada anak dengan kesimpulan yang sesuai dengan maksud anak.

Untuk melakukan mendengar aktif, penerima pesan harus memiliki kemampuan untuk memahami isi pembicaraan orang lain serta berbagai perasaan yang dirasakan oleh pengirim pesan saat sedang mengkomunikasikan pesan yang disampaikan. Penerima pesan ini tidak hanya mendengar kata-kata dari lawan bicaranya, tetapi dalam prosesnya juga harus bisa mendengar pesan yang tersirat dalam kata-kata tersebut. Penerima pesan juga harus berusaha mendengarkan suara, mengamati penampilan serta membaca bahasa tubuh lawan bicaranya. Hal tersebut dilakukan untuk menyerap segala sesuatu yang disampaikan lawan bicaranya baik secara verbal maupun non verbal tanpa menambahkan, mengurangi atau mengubah pembicaraan tersebut (Robertson, 2005).

Menurut Rogers (1987) ada tiga karakteristik yang menjadi indikator seseorang yang mampu mendengar aktif. Pertama, mampu mendengar lawan bicara dengan penuh perhatian dan penuh makna. Hal ini mencakup keseluruhan pesan dan perasaan yang disampaikan dan ditampilkan lawan bicara. Seseorang yang mendengar aktif mampu memberikan respon pesan dan penampilan yang menunjukkan penerimaan melalui penggunaan kata-kata serta kalimat yang tidak menyalahkan, mengkritik berlebihan, menghakimi dan menolak pembicara.

Kedua, mampu memberikan respon dari berbagai perasaan yang dinyatakan melalui teknik parafrase dengan menyatakan kembali apa yang dikatakan lawan bicara untuk menunjukkan empati. Selain itu pendengar juga mampu memberikan umpan balik atau merefleksikan isi ucapan dan perasaan lawan bicara. Ketiga, mampu melakukan komunikasi non verbal (isyarat tubuh) yang meliputi ekspresi wajah, gesture tubuh dan hand movements (seperti tidak melipat tangan ke dada saat berhadapan dengan pengirim pesan), eye movements (kontak mata harus tetap tertuju pada pengirim pesan).

Karakteristik lain dikemukakan Gordon (2009), bahwa kemampuan mendengar aktif tidak hanya terlihat dari ciri-ciri indikator yang muncul saja melainkan juga dari hal-hal yang seharusnya tidak muncul dalam pelaksanaannya. Hal-hal yang "tidak dilakukan" tersebut penting 
untuk dipahami karena pendengar harus bisa menghindari berbagai respon yang biasa dilakukan saat mendengar. Hal ini disebut dengan istilah roadblocks dan termasuk sulit untuk dilakukan. Beberapa respon yang termasuk dalam roadblocks menurut Gordon seperti: memerintah dan mengarahkan, mengancam dan memperingatkan serta mendesak dan memberi ceramah berkepanjangan. Selain itu respon seperti terlalu cepat memberikan nasihat atau solusi, mempengaruhi anak dengan fakta, kontra argumen, logika, atau pendapat pribadi serta cepat menilai, mengkritik, tidak setuju, dan menyalahkan juga termasuk dalam roadblocks. Ada juga respon lain seperti menyetujui atau memuji tetapi tidak tepat pada waktunya, mencemooh dan membuat malu, membuat interpretasi dan analisa pribadi, menghibur, mendorong dan meyakinkan anak namun tidak memberikan penerimaan terlebih dahulu. Terakhir, perilaku seperti menyelidiki, mengusut, menghindar, mengalihkan perhatian, atau menertawakan pembicara juga harus dihindari agar ayah sebagai pendengar bisa memiliki kemampuan mendengar aktif yang baik.

Pelatihan merupakan salah satu cara pembelajaran bagi orang dewasa (Laird, 2003). Sementara Goldstein dan Gessner (1988) menjabarkan pelatihan sebagai upaya untuk mendapatkan ketrampilan, memahami aturan atau konsep atau upaya untuk mengubah sikap demi meningkatkan performa kerja. Mathis dan Jackson (2005) menjelaskan pelatihan sebagai sebuah proses pembelajaran dimana seseorang mampu untuk mendapatkan kapabilitas dalam membantu dirinya mencapai tujuan tertentu. Sikula (2001), mengartikan pelatihan sebagai suatu proses pendidikan jangka pendek dengan prosedur yang sistematis dan terorganisir dalam mempelajari suatu pengetahuan dan keterampilan teknis untuk tujuan tertentu. Definisi lain mengenai pelatihan dikemukakan Basleman dan Mappa (2011) yang menyatakan bahwa pelatihan merupakan salah satu bentuk pembelajaran orang dewasa yang dilakukan dalam kelompok sebagai upaya untuk meningkatkan pengetahuan, ketrampilan, dan sikap dalam mengerjakan sesuatu atau melakukan tugas tertentu.

Peran ayah dalam kegiatan pengasuhan anak ini merujuk kepada fungsi dan peran yang dijalankan ayah saat berinteraksi dengan anak yang meliputi peran sebagai pengasuh, teman bermain, pengajar, pemberi dukungan, model bagi anak dan figur otoritas. Hal ini kemudian disebut dengan istilah fathering (Pleck, 2010). Carlson dan McLanahan (2010) juga memaparkan konsep mengenai fathering yang berkaitan dengan peran ayah sebagai sosok orang tua yang memiliki berbagai aktivitas seperti: mencari nafkah, membesarkan anak dan memberikan kasih sayang, bermain bersama anak di waktu senggang, memberikan panduan moral dan disiplin kepada anak. Selain itu ayah juga berperan dalam aktivitas memberikan dukungan finansial serta emosi maupun fisik kepada ibu, memastikan keselamatan jiwa anak, menjadi penghubung antara anak dengan anggota keluarga inti lain, serta membangun relasi antara anak dengan lingkungan sekitarnya.

Lamb (1997) mengatakan bahwa keterlibatan ayah dalam pengasuhan anak mengacu pada kegiatan pengasuhan langsung dan tidak langsung, serta tanggung jawab ayah atas perkembangan anaknya. Keterlibatan langsung ayah kemudian disebut dengan istilah engagement, sedangkan keterlibatan tidak langsung disebut availability dan bentuk tanggung jawab ayah disebut responsibility. Ketiga bagian ini yang menentukan tingkat father involvement seorang ayah dalam fathering.

Engagement meliputi waktu yang dihabiskan untuk berinteraksi one-on-one dengan anak, misalkan melalui kegiatan 
memberi makan atau bermain. Interaksi yang termasuk dalam engagement tidak termasuk waktu yang dihabiskan untuk melakukan pekerjaan rumah yang berhubungan dengan anak seperti mencuci baju atau membereskan mainan anak. Availability berarti ayah tetap terhubung dan bisa dijangkau oleh anak meski tidak berinteraksi secara langsung. Ayah tetap ada dan anak tetap bisa menjalin interaksi dengannya, misalkan saat ayah memasak atau mencuci piring di dapur sementara anak bermain di ruangan yang berbeda. Responsibility berhubungan dengan peran ayah yang bertanggung jawab terhadap kesehatan dan kesejahteraan anak, misalkan mengatur jadwal kunjungan anak ke dokter, mencari pengasuh lain saat ayah dan ibu ada acara atau keperluan sehingga harus menitipkan anak, menyusun rencana pendidikan anak di masa depan, dan sebagainya.

Keterlibatan ayah dalam pengasuhan tidak hanya dilihat dari 3 unsur di atas. Ayah sebagai orang tua juga memiliki tugas-tugas dalam pengasuhan. Menurut Brooks (2011), ayah yang memiliki anak usia pra sekolah mempunyai tugas antara lain: menyediakan tempat, fasilitas, dan lingkungan yang lebih luas untuk keluarga; menyesuaikan penghasilan dengan biaya hidup dengan anak usia pra sekolah; berusaha untuk lebih matang dalam melaksanakan perannya dalam keluarga; memelihara komunikasi timbal balik yang baik dalam keluarga; mengasuh dan membuat perencanaan untuk anak; menyiapkan lingkungan lain untuk mengembangkan kompetensi anak; berusaha lebih fleksibel dalam menerapkan disiplin pada anak; serta menjadi model yang positif bagi anak bagi anak.

Dalam usaha pengasuhan yang baik ayah memiliki kewajiban untuk melaksanakan tugas-tugas di atas. Hal ini diperkuat oleh Undang Undang Republik Indonesia nomor 39 tahun 1999 mengenai
Hak Asasi Manusia yang di dalamnya juga tercantum mengenai hak anak. Menurut undang-undang tersebut, dalam pasal 57 disebutkan bahwa setiap anak berhak untuk dibesarkan, dipelihara, dirawat, dididik, diarahkan dan dibimbing kehidupannya oleh orang tua atau walinya sampai dewasa sesuai dengan peraturan perundangundangan. Regulasi mengenai kewajiban orang tua untuk memenuhi hak anak juga tercantum dalam Undang Undang Republik Indonesia nomor 23 tahun 2002 yang mengatur tentang perlindungan anak. Dalam undang-undang tersebut disebutkan bahwa upaya untuk memberikan perlindungan kepada anak perlu dilaksanakan sedini mungkin dengan berlandaskan pada asasasas seperti: nondiskriminasi, kepentingan yang terbaik bagi anak, hak untuk hidup, kelangsungan hidup dan perkembangan; serta, penghargaan terhadap pendapat anak. Landasan hukum Undang Undang nomor 39 tahun 1999 dan nomor 23 tahun 2002 ini sudah lebih dari cukup sebagai pedoman bagi ayah selaku orang tua untuk turut berkontribusi dalam pengasuhan anak dan usaha-usaha untuk membantu mengembangkan potensi anak.

Perkembangan anak usia dini dapat dilihat dari berbagai aspek seperti kognitif, psikososial dan bahasa. Menurut Piaget, anak usia 4-6 tahun berada pada tahap pra operasional. Pada tahap ini anak sudah memahami sebuah keadaan yang mengandung masalah lalu menemukan reaksi atau pemahaman untuk memecahkan masalah tersebut. Karakteristik lain dari tahap ini yaitu anak sudah mampu menggunakan pemikiran simbolis, memiliki pemahaman tentang identitas dan sebabakibat (Papalia, 2002).

Perkembangan psikososial anak usia dini dipengaruhi oleh bagaimana anak berinteraksi dengan lingkungan sekitarnya. Anak mendapatkan pengetahuan mengenai cara bersosialisasi dan mengkontrol emosi melalui pengalaman dan pembiasaan. Pola 
perilaku sosial yang umum muncul pada anak usia dini seperti; meniru, bersaing, bekerjasama, menunjukkan simpati dan empati, memperlihatkan dukungan sosial dan berbagi kepada sesama dan perilaku akrab. Sedangkan emosi yang sering muncul pada anak antara lain; amarah, takut, ingin tahu, gembira, sedih, dan kasih sayang (Hurlock, 1971). Menurut Erickson, pada perkembangan psikososial kelompok usia dini, anak berada dalam tahap Industry vs Inferiority di mana anak menampilkan sikap rajin dan ingin produktif. Anak ingin membangun dan menemukan sesuatu, memanipulasi objek, serta mengetahui bagaimana sesuatu bekerja (Morrison, 2003).

Perkembangan bahasa pada anak usia dini ditandai dengan penguasaan sekitar 8,000 kosakata dan sudah memahami penggunaan tata bahasa sederhana bahasa ibu mereka. Contoh yang paling jelas dalam perkembangan bahasa pada anak dalam kelompok usia ini adalah meningkatnya interaksi antara bahasa dan sosialisasi mereka terhadap sesuatu. Hal ini juga berkaitan dengan kemampuan mereka membahasakan simbol atau tanda-tanda non verbal yang berada di sekitar mereka.

Stimulasi yang tepat pada masa perkembangan anak usia 4-6 tahun mampu meningkatkan perkembangan anak secara lebih optimal. Dengan mendengar aktif, ayah mampu mendorong anak untuk menggunakan kemampuan kognitif dan bahasa anak secara lebih maksimal. Selain itu ayah juga bisa melatih anak untuk mengembangkan kemampuannya mengenai dan meregulasi emosi dengan menekankan pada cara berkomunikasi yang bersifat empati dengan teknik parafrase.

\section{METODE PENELITIAN}

\section{Rancangan Penelitian}

Desain penelitian ini termasuk tipe before-and-after study atau dikenal juga dengan istilah pretest/post-test design (Desain Prates-Pascates) yang bermanfaat untuk mengukur perubahan dalam sebuah situasi, fenomena, atau masalah tertentu. Desain before-and-after study dalam penelitian ini dipakai untuk mengukur perubahan tingkat pengetahuan dan keterampilan mendengar aktif partisipan sebelum dan sesudah pelatihan father active listening diberikan dengan memberikan prates dan pascates pada kelompok ayah yang akan dijadikan subjek penelitian. Prates diberikan sebelum partisipan diberikan intervensi sedangkan pascates akan diberikan setelah partisipan diberikan intervensi sebagai bagian dari tahap evaluasi.

Evaluasi dilakukan sebanyak tiga kali. Evaluasi pertama dilakukan dengan menggunakan kuesioner mendengar aktif dan behavioral check mendengar aktif sebelum diberikan intervensi berupa pelatihan. Evaluasi kedua berupa pascates 1 dilakukan seminggu setelah pelatihan diberikan. Hal ini bertujuan untuk memberikan partisipan kesempatan mempraktikkan hasil pelatihan kepada anak di rumah. Evaluasi kedua berupa pascates 2 dilakukan dua minggu setelah pelatihan diberikan. Waktu 2 minggu diberikan untuk melihat perbedaan antara hasil prates dan pascates 1 serta konsistensi hasil pascates 1 dengan pascates 2 .

\section{Subjek Penelitian}

Partisipan dalam penelitian ini adalah ayah yang memiliki anak berusia 4-6 tahun. Metode pengambilan partisipan dengan menggunakan non random sampling dengan tipe purposive sampling. Penelitian ini mengambil partisipan kelompok kecil dengan jumlah 5 orang.

\section{Metode Pengumpulan Data}

Dalam penelitian ini akan digunakan empat jenis alat ukur untuk mengukur pengetahuan dan keterampilan mendengar 
aktif partisipan pelatihan. Dua alat ukur digunakan pada tahap analisa kebutuhan dan penentuan partisipan pelatihan, yaitu kuesioner listening assessment yang dikembangan oleh Burley dan Allen (1995) dan pertanyaan mengenai persepsi ayah dalam berkomunikasi dengan anak yang diajukan melalui wawancara. Kuesioner listening assessment berisi contoh perilakuperilaku dalam berkomunikasi. Partisipan memberikan keterangan hampir setiap saat, sering, kadang-kadang, atau hampir tidak pernah pada setiap item perilaku tersebut yang mewakili kebiasaan berkomunikasi partisipan dengan anak. Pertanyaan wawancara berisi rangkaian pertanyaan yang menitikberatkan pada pola komunikasi partisipan dengan orang tua. Pertanyaan yang diajukan seperti: "Apa yang biasanya dibicarakan ketika Anda dan anak sedang berkomunikasi?" yang dijawab dengan uraian oleh partisipan.

Dua alat ukur lainnya yaitu kuesioner mendengar aktif dan behavioral checklist mendengar aktif. Kedua alat ukur ini akan digunakan pada saat prates maupun pascates untuk mengukur perubahan tingkat pengetahuan dan keterampilan mendengar aktif partisipan sebelum dan sesudah diberikan pelatihan father active listening.

Alat ukur kuesioner mendengar aktif didasari pada simulasi teknik parafrase yang diutarakan Gordon (2009). Teknik parafrase adalah sebuah metode menyatakan kembali apa yang telah dikatakan oleh lawan bicara untuk menunjukkan empati dan memberikan umpan balik atas isi ucapan dan perasaan lawan bicara. Selain itu dalam kuesioner mendengar aktif ini juga dimasukkan respon yang menunjukkan perilaku roadblocks yaitu hal-hal yang seharusnya tidak terjadi atau seharusnya dihindari. Respon yang dimasukkan dalam kuesioner ini dipilih berdasarkan perilaku roadblocks yang muncul saat pengamatan peneliti pada observasi terhadap interaksi ayah dan anak saat kegiatan home visit yaitu memerintah atau mengarahkan anak, membuat analisi pribadi dan terlalu cepat memberikan solusi. Kuesioner mendengar aktif ini terdiri dari 15 (dua belas) pertanyaan dan untuk jawaban yang benar diberi nilai 1 (satu) dan jawaban salah diberi nilai 0 (nol).

Alat ukur behavioral checklist mendengar aktif dirancang berdasarkan adaptasi dari indikator-indikator yang ada pada teori mendengar aktif dari Carl Rogers dan perilaku roadblocks dikembangkan Gordon (2009). Behavioral checklist mendengar aktif ini diisi berdasarkan observasi saat kegiatan home visit yang dilakukan peneliti sebelum dan sesudah memberikan intervensi kepada partisipan. Behavioral checklist ini diisi dengan memberi tanda checklist $(\sqrt{ })$ untuk perilaku yang muncul. Perilaku yang muncul diberi nilai 1 (satu) dan perilaku yang tidak muncul diberi nilai 0 (nol). Total skor yang didapat menggambarkan tingkat keterampilan partisipan dalam menggunakan teknik mendengar aktif pada anak. Behavioral checklist disusun oleh Wulandari (2016) dan telah dimodifikasi untuk menyesuaikan dengan karakter partisipan yaitu kelompok ayah.

\section{Prosedur Intervensi}

Pelatihan mendengar aktif untuk ayah dilakukan selama 3 hari yang terdiri dari 4 sesi. Setiap sesi berlangsung selama 3 jam. Hari 1 dan 2 terdiri dari sesi materi mengenai teori perkembangan anak dan fathering, sementara hari 3 terdiri dari sesi mengenai mendengar aktif dan komunikasi empatis. Pelatihan ini menggunakan metode ceramah, diskusi, roleplay untuk berlatih teknik-teknik mendengar aktif serta memakai media video sebagai penunjang materi. Gambaran pelatihan dapat dilihat pada tabel 1 berikut: 
Tabel 1. Gambaran Pelatihan Mendengar Aktif Untuk Ayah

\begin{tabular}{ccll}
\hline Hari & Sesi & \multicolumn{1}{c}{ Materi } & \multicolumn{1}{c}{ Metode } \\
\hline Hari ke-1 & 1 & Perkembangan Anak Usia Dini & Ceramah, diskusi, games, video \\
\hline Hari ke-2 & 2 & Fathering & Ceramah, diskusi, games, video \\
\hline Hari ke-3 & 3 & Mendengar Aktif & Ceramah, diskusi, roleplay \\
& 4 & Komunikasi Empatis & Ceramah, diskusi, roleplay \\
\hline
\end{tabular}

\section{Analisis Data}

Dalam menganalisis data, peneliti menggunakan uji non-parametrik Wilcoxon Signed Rank dari program SPSS untuk melihat signifikansi dari perubahan yang terjadi.

\section{HASIL PENELITIAN}

Data yang diperoleh pada penelitian ini diolah dengan membandingkan skor pengetahuan dan keterampilan mendengar aktif partisipan pada saat pemberian prates dan pascates 1 serta pascates 1 dan pacates 2. Berikut gambaran hasil data yang didapatkan.

\section{Hasil Skor Pengetahuan Teknik Parafrase}

Hasil penelitian ini didapat dengan menggunakan alat ukur kuesioner mendengar aktif yang diberikan kepada partisipan sebanyak 2 kali saat intervensi pelatihan berlangsung. Kali pertama diberikan sebelum sesi 1 pelatihan diadakan dan kali kedua diberikan setelah sesi 4 pelatihan selesai diadakan. Hasil skor perubahan skor pengetahuan teknik paraphrase partisipan pelatihan bisa dilihat pada gambar 1 berikut.

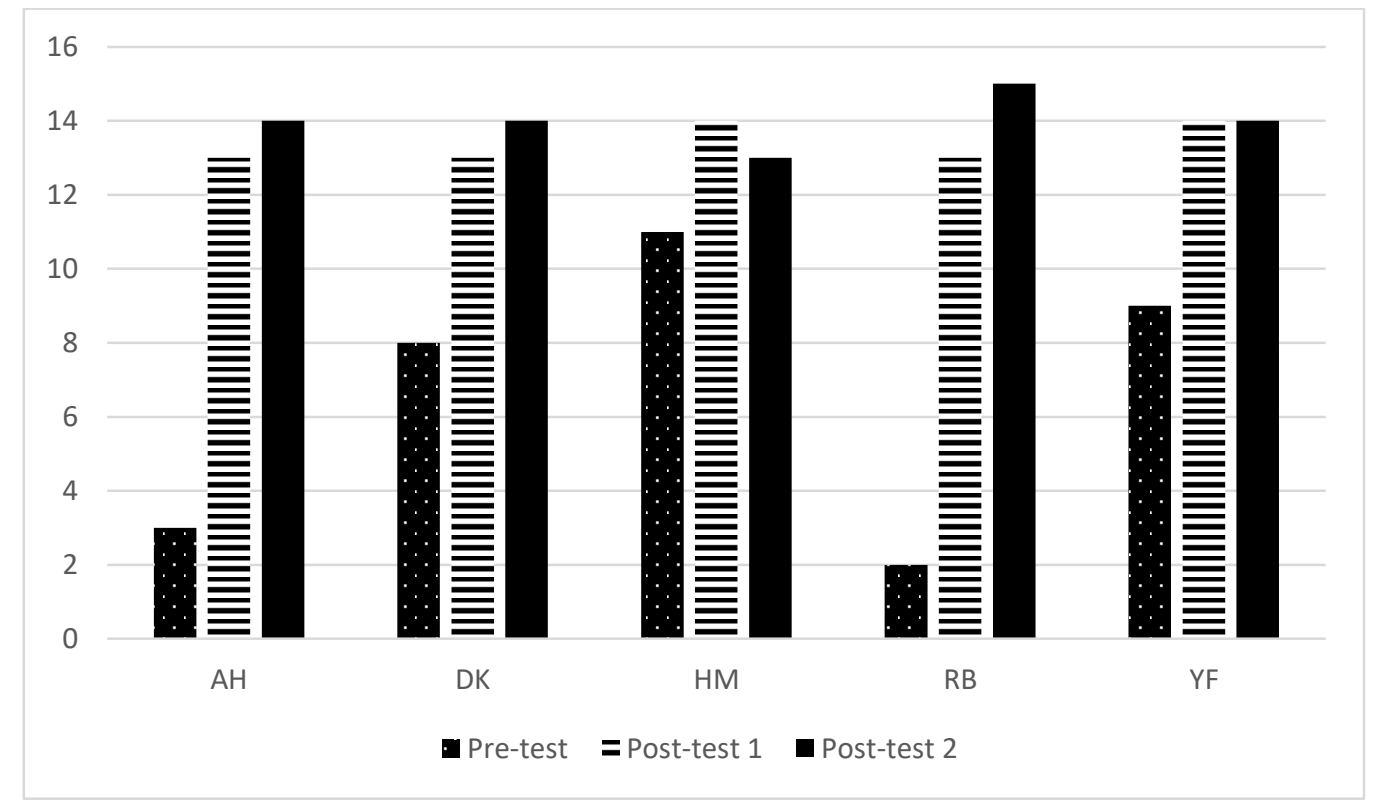

Gambar 1.

Grafik Perbedaan Hasil Skor Pengetahuan Teknik Parafrase Partisipan Melalui Kuesioner Mendengar Aktif 
Gambar 1 menunjukkan tingkat pemahaman sebagian besar partisipan mengenai teknik parafrase masih rendah berdasarkan skor prates. Hal ini menunjukkan pola komunikasi partisipan yang masih kurang terlatih untuk mendengarkan lawan bicara dan sulit menghindari roadblocks tertentu seperti terlalu cepat memerintah, mengancam anak, memberikan solusi atau pendapat pribadi saat mendengarkan. Setelah mendapatkan intervensi pelatihan, semua partisipan menunjukkan peningkatan dalam hasil skor kuesioner. Hal ini terlihat dari hasil pascates 1 yang menunjukkan peningkatan nilai pada skor total partisipan.

Pada pascates 2 terlihat peningkatan pada 3 orang partisipan. Hal ini menunjukkan bahwa pengetahuan partisipan terhadap teknik parafrase dalam menangkap pesan anak meningkat setelah mengalami jeda selama 2 minggu sejak pelatihan diberikan. Partisipan masih mampu membedakan antara kalimat yang menangkap inti pesan dengan kalimat yang menunjukkan penilaian atau perintah. Akan tetapi ada satu partisipan yang mengalami penurunan skor sebanyak 1 poin. Sedangkan skor satu partisipan terlihat tetap yang menunjukkan bahwa pengetahuan partisipan terhadap teknik parafrase masih terjaga meski tidak mengalami peningkatan.

\section{Hasil Analisa Statistik Skor Pengetahuan Teknik Parafrase}

Peneliti kemudian

melakukan uji non-parametrik Wilcoxon Signed Rank untuk melihat signifikansi dari perubahan pengetahuan teknik parafrase partisipan. Hasil uji tersebut dapat dilihat pada tabel berikut ini.

Tabel 2. Tes Statistik - Wilcoxon Signed Rank (Kuesioner Mendengar Aktif)

\begin{tabular}{cc}
\hline & Pre-Post 1 \\
\hline $\mathbf{Z}$ & $2,032^{\mathrm{b}}$ \\
\hline Asymp. Sig (2-tailed) & 0,042 \\
\hline
\end{tabular}

Setelah dilakukan uji non parametrik Wilcoxon Signed Rank, terlihat bahwa nilai Z sebesar 2,032 dan nilai signifikansi p.value $0,042(<0,05)$. $P$ value kurang dari 0,05 menunjukkan adanya perbedaan yang signifikan antara nilai pre-test dan post-test 1 sebelum dan sesudah diberikan intervensi pelatihan.

Peneliti lalu membandingkan hasil antara skor pascates 1 dan pascates 2 dan didapatkan hasil yang bisa dilihat pada tabel 3 berikut:

Tabel 3. Tes Statistik - Wilcoxon Signed Rank (Kuesioner Mendengar Aktif)

Post 1-Post 2

\begin{tabular}{cc}
\hline $\mathbf{Z}$ & $1,134^{\mathrm{b}}$ \\
\hline Asymp. Sig (2-tailed) & 0,257 \\
\hline
\end{tabular}


Setelah dilakukan uji non parametrik Wilcoxon Signed Rank, terlihat bahwa nilai Z sebesar 1,134 dan nilai signifikansi p.value 0,257 (>0,05). $P$ value lebih besar dari 0,05 menunjukkan adanya perbedaan yang tidak signifikan antara nilai pascates 1 dan pascates 2 dalam jangka waktu2 minggu sejak pelatihan diberikan.
Hasil Skor Keterampilan Mendengar Aktif

Hasil penelitian ini didapat dengan melakukan pengamatan kepada partisipan dalam melakukan teknik mendengar aktif. Pengamatan dilakukan sebanyak 3 kali; 1 kali sebelum diberikan intervensi dan 2 kali setelah diberikan intervensi pelatihan. Pengamatan dilakukan dengan metode home visit. Alat ukur yang digunakan adalah behavioral checklist mendengar aktif. Hasil skor perubahan perilaku partisipan pelatihan bisa dilihat pada gambar 2 berikut.

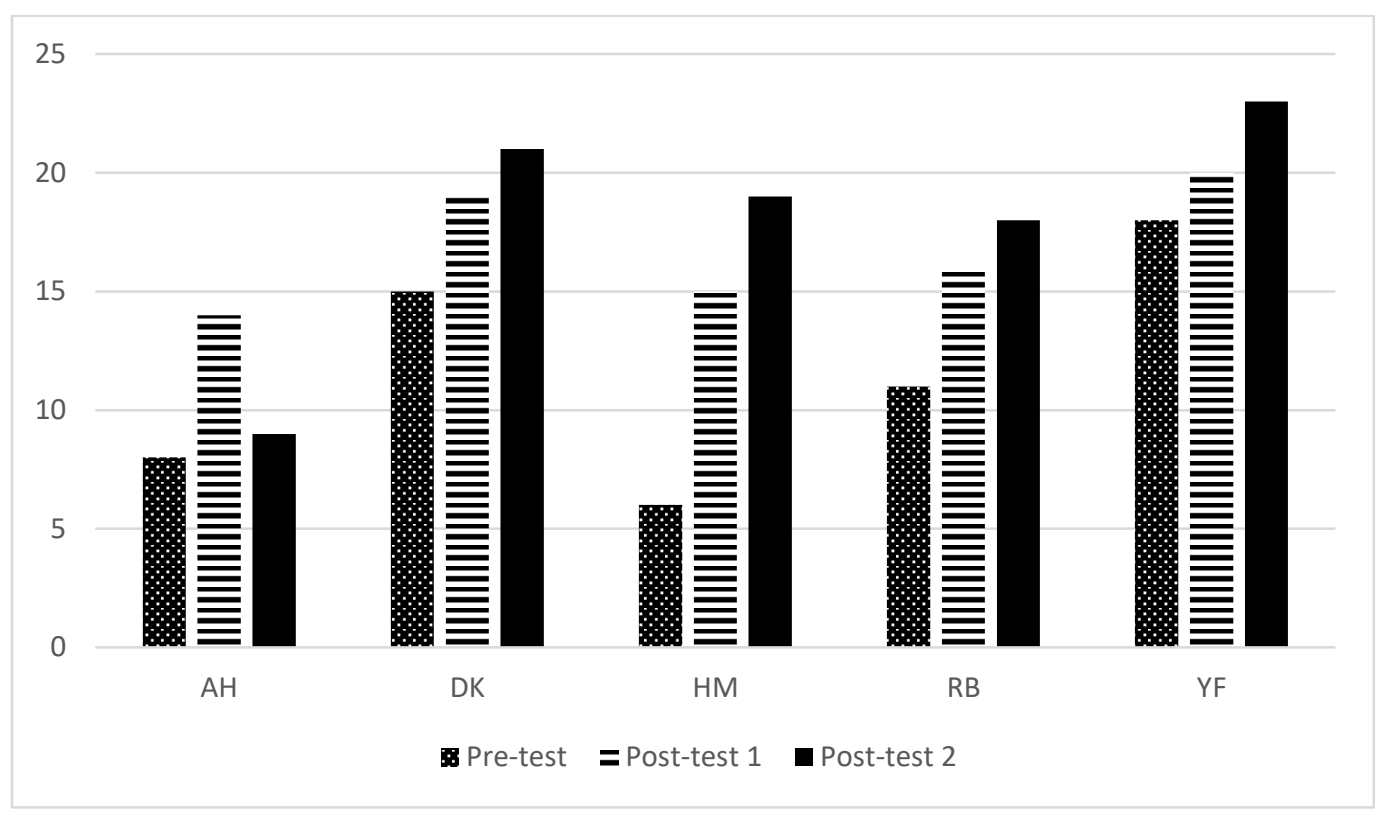

Gambar 2.

Grafik Perbedaan Hasil Skor Keterampilan Mendengar Aktif Partisipan Melalui Behavioral Checklist Mendengar Aktif

\footnotetext{
Berdasarkan gambar 2. secara penurunan yang cukup besar yaitu sebanyak umum semua partisipan mengalami peningkatan pada skor prates dan pascates 1. Peningkatan paling pesat terjadi pada 2 partisipan yang mengalami peningkatan sebanyak 9 dan 7 poin. Hal ini menunjukkan bahwa peserta memahami teknik-teknik mendengar aktif dan melakukannya saat mengasuh anak di rumah.

Untuk skor pascates 1 dan pascates 2 terjadi peningkatan pada 4 orang partisipan, akan tetapi pada satu partisipan terjadi 5 poin. Secara umum, skor mayoritas partisipan setelah intervensi lebih tinggi dari hasil skor sebelum intervensi dan mengalami peningkatan. Hanya ada 1 orang partisipan yang mengalami penurunan yang dilihat dari skor pascates 2. Gambar 2. juga menunjukkan adanya peningkatan keterampilan partisipan dalam melakukan teknik mendengar aktif di rumah saat bersama anak walau konsistensi dalam melakukannya mengalami penurunan.
} 


\section{Hasil Analisa Statistik Skor Keterampilan Mendengar Aktif}

Pada skor keterampilan mendengar aktif, peneliti kembali melakukan uji nonparametrik Wilcoxon Signed Rank untuk melihat signifikansi dari perubahan keterampilan mendengar aktif partisipan. Hasil uji tersebut dapat dilihat pada tabel berikut ini.

Tabel 4. Tes Statistik - Wilcoxon Signed Rank (Behavioral Checklist Mendengar Aktif)

\begin{tabular}{cc}
\hline & Pre-Post 1 \\
\hline $\mathbf{Z}$ & $2,023^{\mathrm{b}}$ \\
\hline Asymp. Sig (2-tailed) & 0,043 \\
\hline
\end{tabular}

Berdasarkan hasil perhitungan menggunakan Wilcoxon, terlihat bahwa nilai $\mathrm{Z}$ sebesar 2,023 dan nilai signifikansi p.value $0,043(<0,05)$. $P$ value kurang dari 0,05 menunjukkan adanya perbedaan yang siginifikan antara hasil skor prates dan pascates 1 sebelum dan sesudah diberikan intervensi pelatihan.

Peneliti lalu membandingkan hasil antara skor pascates 1 dan pascates 2 dan didapatkan hasil sebagai berikut:

Tabel 5. Tes Statistik - Wilcoxon Signed Rank (Behavioral Checklist Mendengar Aktif)

\begin{tabular}{cc}
\hline & Post 1-Post 2 \\
\hline $\mathbf{Z}$ & $0,677^{\mathrm{b}}$ \\
\hline Asymp. Sig (2-tailed) & 0,498 \\
\hline
\end{tabular}

Setelah dilakukan uji non parametrik Wilcoxon Signed Rank, terlihat bahwa nilai Z sebesar 0,677 dan nilai signifikansi p.value $0,498(>0,05)$. $P$ value lebih besar dari 0,05 menunjukkan adanya perbedaan yang tidak signifikan antara nilai pascates 1 dan pascates 2 dalam jangka waktu2 minggu sejak pelatihan diberikan.

\section{PEMBAHASAN}

Berdasarkan kesimpulan dalam penelitian ini, ada beberapa hal yang dapat dijadikan pembahasan lebih lanjut. Program pelatihan mendengar aktif untuk ayah dengan anak usia 4 hingga 6 tahun menunjukkan peningkatan terhadap pengetahuan, keterampilan serta kesadaran ayah terhadap pentingnya peran ayah dan pentingnya kemampuan yang harus dimiliki dalam mengasuh anak usia dini. Hal ini didukung oleh rancangan pelatihan yang memperhatikan unsur-unsur pendukung seperti partisipan yang spesifik, penggunaan alat ukur yang baik dan spesifik, dilaksanakan pada kondisi dan waktu yang spesifik sehingga dapat menghasilkan nilai yang tinggi yang merupakan syarat untuk meningkatkan efektifitas pelatihan menurut Emzir (2009).

Materi perkembangan anak usia dini dan fathering dapat membantu partisipan membuka wawasan terhadap dunia parenting anak. Selain itu dengan memberikan materi yang memfokuskan pada peran ayah dalam pengasuhan, partisipan lebih mampu untuk menangkap gambaran besar tugas dan pengaruh mereka terhadap proses tumbuh kembang anak. 
Materi lain yang bisa membantu meningkatkan efektifitas pelatihan adalah materi mengenai komunikasi empatis. Menurut Rogers dan Farson (2007), mendengar aktif hanya efektif dalam tataran mengubah perilaku seseorang. Untuk membuat seseorang menghayati dan terampil dalam mengaplikasikan teknikteknik seperti parafrase dan mengingat detil pesan yang disampaikan orang lain, diperlukan kemampuan lain yaitu empati. Oleh sebab itu sebuah pelatihan mendengar aktifakan memperoleh hasil yang lebih baik jika digabungkan dengan materi mengenai mendengarkan secara empatis.

Hal berikutnya yang bisa meningkatkan efektifitas pelatihan adalah dengan menggunakan metode yang tepat dan menarik seperti penggunaan video untuk memberikan gambaran konkrit mengenai materi tertentu serta permainan dan roleplay untuk memberikan partisipan pengalaman langsung dalam mencoba mengaplikasikan teknik-teknik yang diajarkan. Penggunaan video cukup efektif untuk menunjang penjelasan materi yang diberikan saat pelatihan. Pemilihan video yang tepat mampu meningkatkan pemahaman partisipan terhadap materi yang disampaikan. Untuk pelatihan mendengar aktif untuk ayah ini video yang digunakan sebagian besar masih berupa adegan antara orang dewasa sehingga sebagian partisipan masih kesulitan dalam memahami cara-cara berkomunikasi dengan anak. Penggunaan metode roleplay juga efektif untuk membuka wawasan ayah dan mengajak ayah merefleksikan kembali perasaan dan pikiran yang mungkin belum disadari. Melalui roleplay ayah dapat melihat dari sudut pandang lain bagaimana cara berkomunikasi dan berinteraksi dengan anak dengan menempatkan diri mereka sebagai anak. Dengan penggunaan metode yang tepat, motivasi para peserta bisa ditingkatkan sehingga keberhasilan pelatihan akan semakin besar. Hal ini sesuai dengan pernyataan Knowles (2005) yang mengatakan bahwa salah satu faktor keberhasilan pembelajaran orang dewasa dipengaruhi oleh motivasi orang dewasa tersebut sebagai pembelajar.

Keterlibatan partisipan dalam pengasuhan anak juga berperan besar dalam peningkatan pengetahuan dan keterampilan dalam mengaplikasikan teknik-teknik mendengar aktif. Menurut Lamb (1997) ada 3 elemen penting dalam mengukur tingkat keterlibatan ayah yaitu engangement, availability dan responsibility. Pada hasil penelitian ini diketahui bahwa peningkatan pengetahuan mendengar aktif partisipan berbanding lurus dengan peningkatan keterampilan partisipan dalam mengaplikasikan teknik-teknik mendengar aktif saat berkomunikasi dengan anak. Partisipan yang memiliki tingkat engagement yang tinggi akan semakin tergerak untuk lebih mendengarkan anak. Hal ini membuat availability partisipan turut meningkat sehingga anak memiliki kesempatan lebih besar untuk menjangkau partisipan saat mengalami masalah. Dengan mengetahui kebutuhan dan kondisi anak otomatis peran partisipan dalam pengasuhan anak akan meningkat pula sehingga tingkat responsibility akan menjadi lebih baik. Jika partisipan kesulitan memenuhi ketiga elemen tersebut, usaha untuk meningkatkan kualitas keterampilan mendengar aktif juga akan sulit untuk dilakukan.

Secara umum pelatihan mendengar aktif untuk ayah mampu meningkatkan pengetahuan dan keterampilan mendengar aktif ayah saat berkomunikasi bersama anak. Hasil yang sama juga ditemukan pada penelitian sebelumnya yaitu pelatihan mendengar aktif untuk ibu yang dilakukan oleh Hafiani (2016). Hal ini dilatarbelakangi oleh rancangan modul pelatihan yang menggunakan landasan teori dan metode yang sesuai dengan karakteristik partisipan masing-masing pelatihan. Pada pelatihan mendengar aktif untuk ayah, modifikasi 
materi parenting menjadi fathering terbukti mampu meningkatkan motivasi partisipan untuk lebih aktif terlibat dalam pengasuhan anak dan meningkatkan kualitas pengasuhan mereka. Hal ini tidak lepas dari isi materi yang menekankan pentingnya peran ayah dan manfaat positif keterlibatan ayah dalam pengasuhan bagi perkembangan anak yang belum diketahui oleh partisipan sebelum mendapatkan pelatihan. Dengan meningkatnya motivasi partsipan untuk lebih aktif terlibat dan menciptakan pengasuhan yang berkualitas kepada anak, maka kenaikan tingkat pengetahuan serta keterampilan mendengar aktif pun menjadi lebih tinggi sehingga pelatihan mendengar aktif untuk ayah pun bisa menjadi lebih efektif.

Pada pelatihan mendengar aktif untuk ayah ditemukan hasil bahwa peningkatan pengetahuan serta keterampilan mendengar aktif partisipan masih terlihat pada pascates 1 yang dilakukan satu minggu setelah pelatihan dan pascates 2 yang dilakukan 2 minggu setelah pelatihan. Hal ini menandakan bahwa ayah memiliki kesadaran untuk terus mengasah keahlian mendengar aktif dengan mempraktekkannya di rumah saat berinteraksi dengan anak. Metode pemberian prates dan pascates dalam pelatihan mendengar aktif ayah juga menggunakan metode observasi langsung oleh peneliti melalui kunjungan ke rumah partisipan, sehingga data yang didapatkan bisa lebih valid dan objektif karena peneliti dapat langsung mengamati perubahan perilaku partisipan dalam kondisi alami saat di rumah. Hasil ini tidak ditemukan pada penelitian sebelumnya karena pengumpulan data pasca pelatihan dilakukan hanya satu kali dengan mengadakan kegiatan Focus Group Discussion (FGD) seminggu setelah pelatihan. Data yang diperoleh melalui kegiatan tersebut belum mampu memberikan gambaran perubahan pengetahuan dan keterampilan partisipan secara objektif karena hanya berdasarkan pendapat atau keterangan partisipan sehingga bisa menciptakan bias persepsi antara partisipan dan peneliti.

Keterbatasan dalam penelitian ini adalah alat ukur kuesioner mendengar aktif yang digunakan belum bisa menampilkan perubahan kualitas pengetahuan mendengar aktif partisipan melalui teknik parafrase secara maksimal. Hal ini disebabkan jawaban kuesioner yang berupa pilihan ganda sehingga kurang memberi kebebasan partisipan untuk memberikan umpan balik yang dapat menampilkan karakteristik masing-masing. Keterbatasan lain adalah pelatihan mendengar aktif ini masih kurang dapat mengikat partisipan untuk mengikuti proses pelatihan karena bersifat sukarela. Selain itu sasaran kelompok partisipan yang berjumlah kecil juga masih belum dapat memberikan manfaat kepada kelompok ayah dalam sakala yang lebih besar. Hal ini juga bisa menjadi hambatan bagi peneliti karena harus melakukan pelatihan berkali-kali jika ingin melakukan intervensi kepada ayah yang lebih banyak dalam lingkup daerah yang lebih besar.

\section{SIMPULAN DAN SARAN}

\section{Simpulan}

Program pelatihan dapat meningkatkan pengetahuan dan keterampilan ayah dalam mendengar aktif. Hal ini diketahui dari hasil analisa penelitian yang menunjukkan terdapat peningkatan dalam skor pengetahuan mengenai teknik parafrase dan perubahan perilaku mendengar aktif partisipan berdasarkan skor prates dan pacates 1. Modifikasi modul rancangan penelitian juga mampu meningkatkan kualitas hasil pelatihan. Hal ini diketahui berdasarkan hasil skor pascates 1 dan pascates 2 yang menunjukkan mayoritas partisipan mengalami kenaikan nilai atau nilai tidak 
mengalami penurunan. Hasil ini membuktikan bahwa pengetahuan partisipan mengenai teknik parafrase yang penting dalam mendengar aktif semakin meningkat seiring dengan keterampilan partisipan yang meningkat saat mengaplikasikan teknik-teknik mendengar aktif yang dipelajari melalui program pelatihan mendengar aktif.

\section{Saran}

Beberapa saran yang dapat diberikan untuk penelitian selanjutnya yaitu:

1. Alat ukur kuesioner mendengar aktif dimodifikasi sehingga menjadi lebih baik lagi dengan mengubah jawaban pilihan ganda menjadi jawaban esai atau uraian singkat. Dengan cara ini pertisipan dapat lebih menggali kemampuan menggunakan teknik parafrase yang penting dalam mendengar aktif. Selain itu peneliti juga dapat lebih detil dalam melihat perubahan pengetahuan mendengar partisipan sehingga data yang didapatkan menjadi lebih kaya dan beragam. Peneliti juga bisa memberikan feedback kepada partisipan untuk memberikan gambaran kualitas pengetahuan dan keterampilan mendengar aktif partisipan dalam periode waktu tertentu.

2. Waktu pelaksanaan pascates 2 diperpanjang menjadi 2 minggu atau lebih sejak diberikan pascates 1 . Hal ini untuk melihat apakah pengetahuan dan keterampilan mendengar aktif partisipan tetap terjaga bahkan meningkat meski sudah tidak mendapatkan pelatihan.
Jika pengetahuan dan keterampilan mendengar aktif partisipan menurun, peneliti dapat mencari strategi untuk meningkatkannya kembali dengan me-refresh materi mengenai teknik-teknik mendengar aktif. Hal ini juga dapat menjaga konsistensi partisipan untuk tetap berlatih teknik-teknik yang sudah dipelajari selama pelatihan agar pengetahuan dan keterampilan yang telah diterima tidak menurun atau menghilang.

3. Saat melakukan latihan parafrase melalui metode roleplay dapat menggunakan video rekaman perkataan atau ekspresi anak. Dapat juga menggunakan rekaman situasi saat ayah mengasuh anak agar partisipan dapat lebih memahami kondisi saat berkomunikasi bersama anak usia dini.

4. Kegiatan pelatihan mendengar aktif utuk ayah bisa melibatkan instansi sekolah agar partisipan lebih yakin dan tergerak untuk mengikuti kegiatan pelatihan. Selain itu dengan melibatkan sekolah, karakteristik partisipan, waktu, lokasi dan hal penunjang lainnya bisa lebih terjamin serta dapat memberikan manfaat bagi kelompok masyarakat yang lebih luas. Fasilitator bisa bekerjasama dengan pihak sekolah untuk membuat program pelatihan khusus ayah yang terintegrasi dengan program sekolah. Orang tua khususnya ayah juga bisa lebih tergerak untuk ikut pelatihan karena kredibilitas sekolah sebagai fasilitator pelatihan. 


\section{Daftar Pustaka}

Andayani, Budi \& Koentjoro. (2004). Psikologi keluarga: Peran ayah menuju coparenting. Yogyakarta: CV. Citra Media.

Bronte, T., J., Moore, K.M., \& Carrano, J. (2006). The father-child relationship, parenting styles, and adolescent risk behaviors in intact families. Journal of Family Issues, 27, 850-881.

Brooks, J. B. (2011). The process of parenting International Edition. New York: The McGraw-Hill Company.

Burley, M., \& Allen. (1995). Listening the forgotten skill. A self teaching guide. 2nd edition. New York: John Wiley \& Sons, Inc

Chorley, M. (2015). Children start school unable to speak because parents are too busy checking their phones to talk to them. PUBLISHED: 11:56 GMT, 5 August 2015. www.dailymail.co.uk.

Eysenck, M. W. (2001). Principles of cognitive psychology (2nd ed.). East Sussex: Psychology Press.

Frey, L. R. (1996). Remembering and "remembering": A history of theory and research on communication and group decision making. Communication and group decision making, 2, 19-54.

Gordon, T. (2009). Menjadi orangtua efektif. Cara pintar mendidik anak agar bertanggung jawab. Jakarta: PT. Gramedia

Hartini, E. (2013). Program pelatihan fathering untuk meningkatkan intensi keterlibatan ayah dalam aktifitas pengasuhan anak di kabupaten garut. Tesis Fakultas Psikologi Universitas Indonesia
Kalat, J. W. (2008). Introduction to psychology (8th ed.). California: Thomson Learning.

Lamb, M.E. (1997). The role of father in child development ( $5^{\text {th }}$ ed.). Hoboken. John Wiley \& Sons, Inc.

Lewis, J. M. (2011). Fathering attitudes and father involvement. Disertasi University of North Carolina.

Lewis, C., \& Lamb, M. E. (2003). Fathers' influences on children's development: The evidence from two-parent families. European journal of psychology of education, 18(2), 211228.

Mc.Graw, P. (2004). Family first. Your step by step plan for creating a phenomenal family. New York: Simon Schuster, Inc

Nelson, P. E., Titsworth, S., \& Harter, L. (2006). Human communication. New York: McGraw-Hill.

Nickels, M. K. (1997). The activity of being there: fathers' roles in their families over time (Doctoral dissertation, research directed by Dept. of Human Development/Institute for Child Study.University of Maryland, College Park, Md.).

Olson, M., \& Hegerhahn. (2011). Pengantar teori-teori kepribadian. Yogyakarta: Pustaka Pelajar.

Osborne, C., \& McLanahan, S. (2007). Partnership instability and child wellbeing. Journal of Marriage and Family, 69, 1065-1083.

Papalia, D.E., Feldman, R.D., \& Martorell, G. (2002). Experience human development (13th ed.). Boston, MA: McGraw-Hill 
Pickard, M. J., Dollahite, D. C., Hawkins, A. J., Lamb, M. E., Lupton, D., Barclay, L., \& Mackey, W. C. (1998). Fatherhood in contemporary society.

Phadke, M. (2015). Working parents, kids have little to say to each other. Times of India : Dec 16, 2015, 11.46PM IST. www.timesofindia.indiatimes.com

Pleck, J.H. (2010). Fatherhood and Masculinity. Dalam Lamb, Michael E. (Ed.) The role of father in child development. (5 ${ }^{\text {the }}$.). New Jersey: John Wiley \& Sons, Inc.

Ramadhani, S (2006). Building positive communication. Mengembangkan EQ dan kepribadian positif pada anak. Jogjakarta: Diglossia Media.

Rogers, C., \& Farson, R. E. (1987). Active listening. Diunduh dari http://www.gordontraining.com Lartman2/uploads/1/ActiveListening RogersFarson.pdf

Rosenberg, J., \& Wilcox W.B. (2006) The importance of fathers in the healthy development of children. US Department Health and Human Services, Administration for Children and Families, Administration on Children, Youth and Families, Children's Bureau, Office of Child Abuse and Neglect.

Rubin, D.C. (1999). Remembering our past: Studies in autobiographical memory. Cambrige University Press.
Solso, R.L., Maclin, O. H., \& Maclin, M. K. (2008). Psikologi kognitif (Edisi 8). (Diterjemahkan oleh M. Rahardanto \& K. Batuadji). Jakarta: Erlangga.

Steiner, C. (2013). The big disconnect: Protecting childhood and family relationships in the digital age. Harper.

Taylor, V. (2013). 58\% of U.S. parents admit to using gadgets to babysit their kids: study. New York Daily News : June 26, 2013, 12:49 PM. www.dailynews.com

Thomas, G. (2014). Keterampilan mendengarkan secara aktif dalam komunikasi interpersonal. Humaniora Vol.5 No.1 April 2014 : 501-509

Tubbs, S. L., \& Moss, S. (2003). Human communication: Principles and context.

Turner, R.D. (2011). How father's style of parenting benefits their children's development. Parents as Teachers. http://parentsasteacher.org

Walgito, B. (2010). Pengantar psikologi umum. Yogyakarta: Penerbit Andi.

Wulandari, H.D. (2016). Efektifitas program pelatihan untuk meningkatkan keterampilan mendengar aktif pada ibu dalam keluarga militer dengan anak usia 4-6 tahun. Tesis Fakultas Psikologi Universitas Indonesia 
Oki Gunawan, Puji Lestari Suharso EDini Pepen Daengsari 